\title{
Impact of Space and Environment on Women in Urban Transformation (Case of Ankara)
}

\author{
Özgür Sarı \\ Assoc.Prof.Dr., TODAiE, 85.cad. No:8 Yücetepe, 06100, Ankara-Turkey
}

\begin{abstract}
In this study, it is understood that Turkey is developing rapidly, the increasing need for accommodation due to migration from the village to the city and the distorted structure in the cities, and the urban transformation efforts carried out in order to overcome this skewed construction necessitated the reorganization of the environment and the place. Urban transformation, which brings about significant changes in social life, causes positive / negative effects especially on the social life of women. In this context, the historical process of urban transformation in Turkey and in the world has been analyzed and discussed from the perspective of environment and women's issues. In this context, it is aimed to analyze the reflections of the new place and the surrounding area, which are the result of urban transformation, on the social life of women, by interviewing face to face with the women living in Etimesgut in the city of Ankara and having experienced the process of urban transformation. In this framework, it is aimed to produce suggestions on spatial planning and environmental regulations that take into account the needs of women in urban life. The fact that women spend more time in domestic life, that women play an active role in neighborhood culture, requires that women be treated as a special category in every kind of urban transformation project and the possible effects on women should be examined. At the end of the work; It has been determined that women are not included in decision-making mechanisms in urban transformation projects carried out in Etimesgut region, that the lifestyles and needs of women are not adequately taken into account when domestic and environmental regulations are being made and that urban transformations have more intense and different effects on women.
\end{abstract}

Keywords: Urban Transformation, Place and Environment, Environment and Women.

\section{Introduction}

Turkey has cities that are shaped by immigration from the countryside and is a rapidly changing country. Rapid migration to urban from rural have brought many problems like lack of infrastructure in the cities, and uneven urbanization. There are many different methods and policies for finding solutions to these problems of our cities. Urban transformations are the most important of these and the largest impact area. The urban transformation projects, which are sometimes painful and sometimes glaring, are a multi-faceted and rapid process carried out not only by the state but also by private construction companies through the Housing Development Administration (TOKI). This process not only transforms the physical appearance and infrastructure of the cities, but also inhabitants' networks, lifestyles, living cultures and social tissues. In this transformation, every part of the society is directly or indirectly affected. The main claim of this study is that women are differently affected by the urban transformation process than men as a separate social category and are involved in urban transformation processes with different parameters. As a result of this work, women are passively becoming objects of this process rather than actively participating in decision-making processes and policy-making processes in the process of urban transformation. The main reason for this is that women in housing ownership are lower than men. Another assumption of this study is that women are not included in the process as a result of urban transformation and that women are not considered as a separate social category in such projects, that renewed housing areas, spaces, environmental regulations are inadequate for women and unsatisfactory. The three major sites in the Süvari Quarter of Etimesgut, the rapidly 
transforming region of Ankara, where the work was conducted, were handled and interviewed with the women who lived in these sites. The women in the sample are the women who settled in the apartments given to them as a result of urban transformation while they were sitting in the slums and their lifestyles changed. Seventeen of the 18 women interviewed were categorized as older than 41 , while 11 were as young. The main reason for distinguishing older and younger women is the assumption that older people can adapt to change more easily. Interviews lasted more than 2 months and the average interview duration lasted about 90 minutes. As the research topic was women, visits were conducted during the evening with their husbands at home. At each interview, 39 questions including demographic questions were asked and the answers were recorded on the voice recorder with permission.

Turkey has cities shaped by immigration from the countryside to the east and is a rapidly changing country. Rapid migration to the city from the sea, lack of infrastructure in the cities, and uneven urbanization have brought many problems to the fore. There are many different methods and policies for finding solutions to these problems of our cities. Urban transformations are the most important of these and the largest impact area. The urban transformation projects, which are sometimes grievous and sometimes brilliant, are a multi-faceted and rapid process carried out not only by the state but also by private construction companies through the Housing Development Administration (TOKI).

This process transforms not only the physical appearance and the infrastructure of the cities, but also your networks, lifestyles, living cultures and social tissues. Every sector of society is directly or indirectly affected by this transformation. The main claim of this study is that women are differently affected by the urban transformation process than males as a separate social category and are involved in urban transformation processes with different parameters.

As a result of this work, women are passively becoming objects of this process rather than actively participating in decisionmaking processes and policy-making processes in the process of urban transformation. The main reason for this is that women in housing ownership are behind men.

Another assumption of this study is that women are not included in the process as a result of urban transformation and that women are not considered as a separate social category in such projects, that renewed housing areas, spaces, environmental regulations are inadequate for women and unsatisfactory.

The concepts that constitute the main axis of the study are discussed in the theoretical discussion in the first part of the thesis on urban, urbanization and urbanism. After the main theoretical discussions about urban, urbanization and urbanization, urban transformation was tried to be defined as a separate concept and international experiences and processes of Turkey were discussed. The most important part of this process, space and environment, has been debated descriptively and conceptually and has been associated with women. The dimension of the space and the space of the woman, the way the women experience the environment and the space, and the issue that they transform the space are also included in the discussion. Urban transformation with different dimensions and the women's issues in international legislation and agreements shed light on the position of women in Turkey in urban transformation. In the programs and regulations of international institutions, women are treated as a separate category in areas such as development, poverty, environment, education and health. It is assumed that women are influenced differently by all these factual processes. For this reason, different policies are set for women.

After discussing the issue of women and environment in Turkey, findings from the field study were discussed. The correctness of the assumptions suggested by analyzing the findings in the discussion and conclusion parts has been tested.

\section{Theoretical Framework}

There are many definitions related to urban transformation. These definitions vary according to the vision, purpose, strategy and method they emphasize. In urbanism, there are many definitions of urban transformation, which are used together with concepts such as renewal, conservation and sanitation that are used to provide reintegration of untouched areas with the city in economic, social and physical terms, but there is no clear definition of this concept in our laws. 
There are also those who understand concepts such as urban regeneration, urban regeneration, urban regeneration, urban regeneration, urban regeneration or urban regeneration, urban regeneration, urban conservation, urban gentrification, depending on the nature and location of the project being implemented. Urban transformation is the whole of the actions and strategies applied to improve the socio-economic, social, environmental and physical conditions of urban areas with collapsing and degradation through integrated and comprehensive approaches.

For the first time, the phenomenon of urban transformation has been resurfaced in the residential areas of the developed western countries in order to reconstruct the depressed areas economically and socially, and in general in the urban areas where the social populations where the population density has been lost or the low-income individuals continue their lives under inadequate economic and unfavorable physical conditions, And the implementation of the projects for the revitalization. The methods of intervening in the spatial shaping of western cities have evolved over time according to the social dynamics of institutional structures peculiar to those societies, with the teaching of errors made (Ataöv and Osmay, 2007: 58-82).

Thomas and Atkinson have described the phenomenon of urban transformation as a comprehensive broad-minded action plan aimed at finding a lasting solution to the economic, physical, social and environmental conditions of the changing regions developed for the solution of urban problems. As a result of change, the region may be a historic settlement, a residential area, or a lost industrial area. According to these theorists, it should be noted that within the frame of urban transformation, concepts such as urban renewal, remediation, revitalization and exacerbation, urban design projects, elaboration and law gentrification are used, and that this process is included in the groups that have a say in legislation, politics, economic decisions and preferences (Akyüz, 2015).

One of the most important assumptions in the context of urban transformation is that cities are entering into intense social and economic relations with new communication possibilities and the decline of the frontiers of the borders, and under the influence of increasingly external dynamics and international or national power balances. In this period, the geographical dimensions of production and hierarchical transformations between cities, the concepts of world cities, called global cities, new industrial centers emerging with new production processes, the relations of local government with democracy, newly created urban areas, new urban centers emerged by the global economy, new The class divisions that have come to the fore depending on the division of labor and the new urban divisions that are shaped by their spatial preferences have come to the agenda (Kurtuluş, 2005: 10).

Urban transformation projects under the supervision of actors active in international and national scales have brought significant problems to the national arena in the future. These activities, which are realized with the projecting mentality, increase the competition between the regions and cities and lead to the subordination of basic values such as transparency, social justice and democracy. It is important that the process is well guided and that the projects of sustainable urbanization are based on the principles of social justice and that the urban transformation projects are first and foremost publicly accepted without damaging the environment by protecting the local characteristics (Çiçek, 2015: 15).

Urban transformation can be carried out in accordance with the socioeconomic and physical conditions of the day, together with a strategic approach to the urban social structure that is worn out, worn out or has a potential value above the existing superstructure value and is generally dominated by poverty, Renewing, altering, developing and revitalizing the action (Özden, 2006: 217).

The first examples of transformation are the gecekondulaşas in the Turkish metropolitan cities with the end of World War II. It is observed that the urban transformation in metropolitan metropolitan cities from the 1950s was classified according to three different cycles. The first period was the period between 1950 and 1980 when the economic growth policy was expanded and the industrialization accelerated. Along with economic growth, immigration has led to the rapid expansion and expansion of large cities. In this period, as the most important urban transformation areas, vacant land in the city was 
transformed into gecekondu neighborhoods and afterwards, with the health conditions of these neighborhoods increased, apartment buildings were restructured and restructured and restructured (Ataöv and Osmay, 2007: 58-82).

In the second period, between 1980 and 2000, when the big cities were influenced by the open liberal economy and globalization. In this period, two important developments were observed in metropolitan cities. On the one hand, licensed and unlicensed or inhabited or incongruous structuring took place in the city, while residential areas spread out of the center. Transformation is observed not only in urban residential areas but also in industrial environments, central and coastal areas. The quality of life has declined over time and has been the repair, rehabilitation or revitalization of risky areas. It is also observed that housing areas of historic value are protected by gentrification.

In the third and last period, the 2000s, the co-operation between the local government and the private sector accelerated, for the first time the 'transformation' was defined as a strategy. However, the transformation strategy is defined as urban restoration only, and this approach has begun to be applied to transform different urban parts into different uses. In addition, the gentrification of historic housing areas and the improvement of apartment / residential areas are striking. Historical analysis shows that intervention in Turkey without knowing and learning the contextual features of transformational areas can not go beyond limited physical change.

Taking into account the local characteristics of the area to be transformed in accordance with the current new planning and intervention paradigm requires the involvement of other claimants with the local government, the establishment of partnerships and the management of a multi-faceted transformation process. There is a need for a new approach in this direction for the transformation applications that will be implemented in the future (Ataöv and Osmay, 2007: 58-82).

Urban transformation requires that different disciplines work in a synchronized manner in the transformation planning studies, as the fields of activity and natural structure affect the whole city identity and the characteristic feature of the city on the existing city structure and the physical, social and economic future of the individuals living there. In this context, it is stated that urban transformation studies should be designed in consideration of 5 basic purposes while being passed on to a misadventure (Şişman and Kibaroğlu, 2009).

A non-indirect relationship should be established between the structural / physical conditions of the city and the social problems and the projects should be developed in such a way as to prevent social deterioration.

Urban transformation should respond to the need for change by allowing the city to constantly renew itself and develop again according to the new physical, social, environmental, infrastructure and economic needs emerging along with the rapidly growing, developing, changing and distorted texture of the city. Urban transformation projects should aim to improve the city's welfare level and quality of life by developing strategies that will restore the economic viability that has disappeared over time.

Projects should be developed by putting forward strategies to prevent urban sprawl from being used in the most effective way together with transformation of urban areas. Thus, reuse of previously used but dispossessed areas will occur and overdispersion will be limited.

Urban politics, the product of political forces with social conditions, must be achieved through a multi-stakeholder planning and design process aimed at meeting the need for reshaping. A planning approach should be adopted that ensures the participation of different segments of society and non-governmental organizations as well as public and private sector participation (Selçuk and Aydoğdu, 2014:39).

Modern and safe cities should be built and existing ones should be renewed with urban transformation projects. Modern cities should be created with the urban transformation that is compatible with the environment in which our people live in peace and security, safe against depression and disaster risks, and compatible with planning standards. 
In this way, the cities will be brought to the country while the unhealthy growth of the cities and the destruction of the agricultural lands are prevented and the other side is safe against the earthquake risks.

Urban transformation projects will prevent the loss of life in earthquakes, the country economy will be minimally damaged and new employment areas will be opened to contribute to revitalization of the construction industry.

\section{Methodology}

The three major sites in the Süvari Quarter in Etimesgut, the rapidly transforming region of Ankara, where the work was conducted, were handled and interviewed with women who lived in these sites. The women in the sample are the women who settled in the apartments given to them as a result of urban transformation while they were sitting in the slums before and their lifestyles changed. Seventeen of the 18 women interviewed were categorized as older than 41 , while 11 as younger were categorized as younger than 41 . The important reason for distinguishing older and younger women is the assumption that younger ones can adapt to change more easily than older ones.

Interviews lasted more than 2 months and the average interview duration lasted about 90 minutes. Since the research topic was women, visits were conducted during the evening with their husbands at home. At each interview, 39 questions including demographic questions were asked and the answers were recorded on the voice recorder with permission. While demographic questions were 8,8 were related to decision making process, 6 were related to environmental regulation, 8 were related to housing property, 6 were related to social life and lifestyle, 2 were about housing width and number of rooms, 1 about family relations, 1 about complaints 1 related to the rules, 1 regarding the rules and 1 question about the security.

\section{Findings}

The interviews were conducted with the women living in the city of Etimesgut and experiencing the urban transformation process was conducted to analyze the reflections of the new space and the surrounding area on the social life of the woman as a result of urban transformation.

Seventeen of the 18 women interviewed were categorized as older than 41 , while 11 as younger were categorized as younger than 41 . The important reason for distinguishing older and younger women is the assumption that younger ones can adapt to change more easily than older ones.

Of the 18 women in the sample, 11 of them are married and have children, while 7 are housewives and 4 of them are working in different jobs. Of the young women, 10 have 2 or fewer children, while only one has 3 . In addition, 6 of the 11 women interviewed were high school, associate and university graduates while 5 were in primary and secondary education. Ten of the women in the young sample did not sit in the apartment or the apartment on the site of the urban transformation process or the one on the site.

Among the women who are categorized as 41 years old and over, 7 are married and housewife, 6 are 2, and 1 child is not. Moreover, while 6 were primary and secondary school graduates, 1 did not go to any school. Older women did not sit in the apartment or the apartment on the 2nd floor of the apartment or the site on the 5th stage of urban transformation.

Women over the age of 41 live in the neighborhood where they live between 24 and 30 years, young women under the age of 41 live between 11 and 35 years. When evaluated in terms of their demographic characteristics, all women are married while young women have higher levels of education and work compared to older women.

Children's ownership rates vary depending on age, while younger women under age 41 are more likely to have 2 or fewer children, while children over 41 years of age and over are 2 or older. Women, together with urban residents, are expected to increase their level of education with new residents. 
In the urban transformation decision-making process, 8 out of 11 young women aged 41 and under did not take part in the decision-making process and 3 took place in the decision-making process. Of the 41 aged and over 7 older women, 6 were in the decision-making process and only 1 were not in the decision-making process. Urban transformation was not included in the decision-making process while 9 of the interviewees were in the process. Although younger than 41 years of age are more effective, younger people under the age of 41 are less likely to take part in the process because their lands have been passed on to them through inheritance.

While 17 respondents favor positive / negative opinions of the 18 interviewers who are involved in the urban transformation, only 1 interviewer has negative thoughts. Women are coming closer to transformation with the idea that urban transformation will be more clean, healthy, warm and pleasant. Interviewees have been taken to different views because their houses are not involved in the planning and construction phases, and the Municipality or the Contractors have decided on the planning and construction stages.

The fact that women spend more time than men have in men's dominant world rather than women, and that the houses for financial gain turn into more and more concrete floors of concrete. With the urban transformation, they are pleased with the environmental regulation of the neighborhoods they are together with, and about the environmental regulation of their houses (park, garden, etc.). Of the 7 elderly women aged 41 and over, 6 are satisfied but only 1 is not satisfied.

Interviewers are often seen in the pictures below, where they feel a 2nd class when compared to other places where they are not satisfied with the environmental system and the lack of green spaces and the children's playgrounds are not adequate and orderly. A noticeable difference in the children's park areas and green areas of Simgeşehir 1 and 2.

The urban transformation that is determined by the Municipality of Etimesgut has been constructed by the contractor firm that is similar to a different area to the gecekondu owners, or the ones who want to be the host from the area where the gecekondu is located are hosting by meeting the price difference between them.

With regard to the positive and negative situations that have taken place in transportation with urban transformation, 6 out of 11 young women aged 41 and under expressed relief in transportation, and they stated that the 5 'si did not come to a change in transportation. 6 out of 7 elderly women aged 41 and over reported positive developments in transportation and only 1 had no change in transportation.

Twelve of the 18 females stated that there were supposedly positive thoughts in transportation arrangements, while 6 said that they did not come to change in mass transportation. Negotiators generally call for environmental improvements as well as new ways of making improvements, a decrease in slope and slope areas, and favorable developments in consequent transportation.

In the analysis of the effect of the apartment or the site fees on the social life of the apartment or site in the life of the apartment or the site, they consider that they do not regard 9 of the 11 younger women under age 41 as expenses and 3 as the expense. Only one of the 7 elderly women aged 41 or older considers 6 as additional costs as additional costs.

The appraisal of the apartment or site dues evaluates only 3 of the 18 fathers who do not perceive 15 as additional costs as an additional expense. The subsidies have contributed to the social lives of women and have provided cleaner and more spacious living spaces.

In the analysis of ownership ownership of new settlement areas and housing realized within the context of urban transformation, 9 out of 11 young women aged 41 and under do not own ownership while only 2 ownership ownership. The 41-year-old and above 7-year-old woman interviewed only 5 of them ownership, while only 2 own the property. The interviewer is not directly entitled to ownership of 14 of the 18 fathers, while only 4 women are registered to the court on behalf of the property owner. Ownership is mostly registered with the spouse or father-in-law, while the proportion of women is very small. 
When analyzed in terms of the number of households residing in Housing Property, the number of people living in the household of 7 elderly women aged 41 and over is 2 and above. Eleven women under the age of 41 have 2 or more in the household. While 18 women interviewed 17 in their house 2 and they were living with the household members, only 1 was staying with their spouse.

When the amount of income entering the residence is taken as the minimum wage reference, 9 out of 11 young women aged 41 and below have a minimum income level of 3 with a minimum wage level. 3 of the elderly aged 41 and over have a minimum income level of 4 and a minimum wage. 18 women interviewed had 11 more than the minimum wage level and 7 were the income level minimum wage.

Young women aged 41 and below have more income than women aged 41 or older because their education levels are high and they are involved in working life. With the urban transformation, the changes in the kitchen expenditures are expressed in the fact that 6 out of 11 young women aged 41 and under are experiencing an increase in the kitchen expenses, while the 5 'si states that they do not come to a change in the kitchen expenses. 4 out of 7 elderly women aged 41 and over are experiencing an increase in kitchen expenses and 3 of them say that kitchen expenses do not change. With Urban Transformation, 18 women interviewed stated that 10 had an increase in kitchen expenses, 8 said that there was no change in kitchen expenses.

It is seen that women are able to contribute to kitchen or household expenses before urban transformation, while canvassing, growing vegetables in the garden, and at the same time washing carpets in front of their homes and decreasing their contribution to the household budget.

Analyzing the change in clothing or household goods with urban transformation, 9 out of 11 young people aged 41 and under are saying that they do not want to change in clothing or household goods, whereas 3 says that they have changed in clothing or household goods. Of the elderly women aged 41 and over, 6 out of 6 said that they only change in household goods, while only 1 says that they do not change in clothing or household goods. 18 women say that the interviewer does not seem to be able to change clothes or household items, but says that 8 does not come to change in clothing or household goods.

Women are generally understood to be changing clothing and household goods in line with their needs. It is understood that 41 year old and younger women are less likely to change than older women aged 41 or older, and that the change is due to the aging of the products used by women aged 41 and older for many years.

Prior to urban transformation, only 17 of the 18 women living in the slum district receive assistance from the municipality or any institution or agency. Interviewer women say that the life of the site or apartment is tranquil, orderly and orderly.

After the urban transformation, neighborhood relations have begun to take place with the permission of weakened departure I arrival. It has been found that it is difficult to find new neighbors with urban transformation and there are warmer neighborhood relations in the slum life. It is understood that with the urban return, changes also take place in the relations of relatives.

11 women aged 41 or younger and 7 women aged 41 or older and 4 adults aged 41 or older felt that they had a new place after the urban transformation, and that they felt they belonged to the slum life. 4 of them belong to the slum life and 3 of them belong to the apartment or the site life. It is understood that 11 of the interviewer's feelings belong to the slum life and 7 that they feel belong to the apartment or the site life.

Women who are transported to your premises as part of urban transformation are more formally perceived as having a more intimate life together with the fact that the physical conditions in the slum life are difficult and the physical conditions of the apartments are beautiful. Women believe that the urban transformation will be preserved not only in the form of 
apartment blocks but also in the horizontal and single or double storeyed individual spaces as well as the neighborhood concept.

Women who continue their lives in the slum before the urban transformation are convinced that there is a lack of rooms and that their houses are not spacious enough. They also say that they do not even have toilets in their houses. But they believe that they have a certain spacious spaces together with urban transformation.

They say that 7 out of 11 young women aged 41 and under are having a positive change in the fact that the spaces bring about changes in family relations, and they say that they do not come to a change in family relations. 4 of the elderly women aged 41 or over say that positive changes in family relations are occurring in their new housing after the end of urbanization, 3 says that they do not come to a change in family relations. The interviewer said that 11 of the 18 females said that positive changes took place, while the 7 said that they did not change the family relations.

As a result of urban transformation in general, women are generally dissatisfied with the materials and workmanship used in the apartment or the site, and the rooms are large and the sun is generally enjoyed.

Of the 18 women interviewees who were informed about the rules of the apartments and the site, only 17 interviewees were informed about the rules, and only 1 interviewer said that they had no knowledge of the rules.

The women are more likely to continue their habits of slum life, resulting in the deletion of carpets or table cloths from the balcony, leaving them to the entrance of the flats.

For safety reasons, 10 out of 11 young people aged 41 years and under are safer than a shanty house or apartment building, only 1 said it is safer. Seven-year-old and older women say that the 7'side site or apartment is safer. Of the 18 women interviewed, only 1 said the saucer was safer. Women feel more secure about the physical characteristics of the apartment or site life, although they do not feel secure about their interest in the physical condition of life in the shantytown.

\section{Conclusion}

Women who have begun to be treated as separate social categories exhibit distinct characteristics from men in terms of their impact on urban regeneration and environmental regulation from developmental processes, social change and transformation, environmental change and disaster, poverty and violence. Every social phenomenon and event affects women with different parameters according to men. For this reason, the main axis of this study has been the dimension of women affected by urban transformation.

It is understood that the women who are selected from the urban transformation area in the Ankara Ili Etimesgut District Süvari Quarter, which is the area of the worker, are affected by different processes from men and have different demands and expectations. In particular, it is understood that women are more actively involved in home use than men. It is understood that males are less used than housewives because they are more active in fields such as business life or social life outside the home. The structure of the house also affects the usage habits of the woman. Woman, the main actor of domestic labor, is a social category that is directly influenced by urban transformation from any politics of residential areas, spatial arrangement. For this reason, it is necessary to consider women as a separate category in the process of urban transformation.

Addressing women as a separate category in terms of being influenced by social processes has also affected international processes. Global organizations such as the United Nations and the European Union, in particular the development and environmental policies, have chosen to pursue separate arrangements and treaties for women. Urban transformation projects that are impossible to think independently of development and environment should also consider women as a separate category and should include policies and practices that consider women in their processes. 
In this study, it is understood that in the light of the data obtained from the interviews conducted with the women in the field within the field, women are clearly behind in housing ownership compared to men, and they can not participate in decision making mechanisms and implementation processes about housing conversion. Women who are in a minority status in residential property are negatively affected by urban regeneration because they are less involved in policy-making and decision-making processes. It is difficult to keep up with the decline of rule and neighborhood cultures related to new housing styles, environmental regulations, new forms of relationships brought about by spatial change, housing use in new sites, resulting from urban transformation.

Another important demographic factor outside gender is thought to be age. It is assumed that older women will have difficulty in adapting to younger women. But as a result of the study, it was understood that the expectation of the elderly is lower than the youth, and that they are satisfied with the current transformation. The elderly are pleased with activities such as fuel and heating system shifts to boilers and boilers, hot water supply, parking arrangements, while younger people with higher expectations have indicated that regulations should be of higher quality and stressed that expectations are not fully met.

Apart from this, the decrease of social relations, the beginning of neighborhood culture disappearance, the emergence of site rules for housing use have made the elderly more difficult. Socio-cultural adaptations of older women are more difficult than young people.

The urban transformation area is the slum region. Some of the houses built in the gecekondu area have been given to landowners. There are big differences in the quality of the residential properties owned by the landowners and the quality of the residential properties that are sold to the market and where the new residents are located. This leads to comparisons and increases dissatisfaction. There is a difference in quality between many environmental and infrastructure arrangements, from the parking area to the entrance door or the pavement infrastructure between the two sites that are selected for the sample and whose photos are included.

In terms of housing ownership, a total of 4 women, of whom only 2 are young and 2 are elderly, own the property. Less than $25 \%$ as a percentage. He stated that only 9 out of 18 females were considered to participate in decision-making mechanisms. The participation of older women is higher than that of young people. It is understood that the young women who come to the house because of the inheritance of the houses are unable to participate in the mechanism.

Women are actors who spend more time in the field of housing as domestic labor and actively use and design housing. Apart from this, women are the main actors who reproduce social relations in the neighborhood culture, live the neighborhood institution and create the neighborhood culture. In the new way of life brought about by spatial arrangements, neighborhood culture is diminishing, and with newcomers, neighborhood culture and neighborhood relations are also transformed. This reduces the amount of time women spend outside the home and makes the neighborhood a safe and secure environment. On the other hand, it is understood from the photographs used previously that the owners of the slum areas settled in the new housing areas continue to maintain their old lifestyle and in the end they display images that do not match the new housing areas. An example of this is to keep the habit of staying away from slum life, such as drying clothes on the balcony or putting shoes on the outside of the door. This situation also causes problems such as violation of site rules, incompatibility between neighbors and decrease of neighborhood solidarity. This leads to an increase in the social divide between the new settlers and the shantytown owners.

The continuation of old habits of shantyowners leads to the continuing non-urban lifestyles in a relational and social sense in a materially urbanized setting. Louis Wirth's theoretical work does not seem to have occurred. In our country, which is the city view in the sense of the building, it is understood that in general, urbanization is interpreted only as the modern sites, the construction of residential areas and the increase of population density. On the other hand, behaviors that are specific to urban life, social patterns, lifestyles, living culture and social networks are missing. In our selected area for the sample, it is seen that the urbanization process and urban transformation that Turkey has experienced fast. 
But in general, all but one of them stated that they were happy in the process and declared a positive opinion. Despite all the shortcomings, women are happy because they are housing owners because it is a relatively expensive and difficult process to obtain housing and access to housing in Turkey. The fact that slums are not precarious, unsecured and unhealthy according to modern and western dwellings, and the possibility of a demolition decision make women happy to have modern and worshiped dwellings. Since the slums are built on the land of the treasury, they are provided with houses that are worshiped with gecekondu owners. It is understood that the women who think positively are not entirely positive and have an appreciation. Despite their positive attitudes, demands and desires, such as a garden home or a fear of a reduced neighborhood and neighborhood environment, are accompanied by positive answers. The disappearance of gardens and green areas, the decline of children's parks and playgrounds, and the diminishing of out-of-home living spaces, such as the fact that women live in squatter courtyards and in front of the gates, are the most frequently highlighted complaints.

Environmental regulations in residential areas are mostly directed at children and women. These areas are mostly used by children and women. Because the most women are responsible for children throughout the day, the low number of areas for children also affects women. For this reason, environmental regulations are relatively weak in urban transformations that do not consider women and children as a separate social category and do not take this situation into consideration in their projects, while green areas, children's playgrounds and parks are relatively small. Since these requests are not addressed by women who are excluded from participation opportunities and decision-making mechanisms, housing in the urban transformation areas is transformed into modern and urban prisons for women and children.

\section{References}

[1] Akyüz, E. (2015). "Çevre Sorunları vee İnsan Hakları Ilişkisi” Akademik Sosyal Araştırmalar Dergisi, Vol. 3, No.15.

[2] Ataöv A., S. Osmay,( 2007): "Türkiye'de Kentsel Dönüşüme Yöntemsel Bir Yaklaşım”, Orta Doğu Teknik Üniversitesi Mimarık Fakültesi Dergisi, Sayı: 2007/2, Ankara, s. 58-82

[3] Çiçek, Z. (2015). Kentsel Dönüşüm ve Kentsel Yoksulluk: Denizli Örneği” Pamukkale Üniversitesi Sosyal Bilimler Enstitüsü Yüksek Lisans Tezi Genel Sosyoloji ve Metodoloji Ana Bilim Dalı Sosyoloji Bilim Dalı. Denizli.

[4] Kurtuluş, H. (2005) "Bir Ütopya Olarak Bahçeşehir", İstanbul'da Kentsel Ayrışma:Mekansal Dönüşümde Farklı Boyutlar İçinde, Derleyen: H. Kurtuluş, Bağlam Yayınları, İstanbul, s:77-12

[5] Özden, P. P. (2006). "Türkiye'de Kentsel Dönüşümün Uygulanabilirliği Üzerine Düşünceler". I. Ü. Siyasal Bilgiler Fakültesi Dergisi, 215-233.

[6] Şişman, A. and Kibaroğlu, D. (2009). 12. Türkiye Harita Bilimsel ve Teknik Kurultayı. "Dünya'da ve Türkiye'de Kentsel Dönüşüm Uygulamaları", Ankara: TMMOB Harita ve Kadastro Mühendisleri Odası.

[7] Selçuk, B. and Aydoğdu, İ.B. (2014). "Kentsel Dönüşüm Üzerine Düşünceler: Kazanım Mı Kayıp Mı?” C.Ü. Iktisadi ve İdari Bilimler Dergisi, Vol. 15, No. 2, 39-42. 